\title{
Research on the Construction of Innovative Practice Base for Graduate Students
}

\author{
Shixin Li, Kaixin Li, Yang Cao \\ Tianjin University of Technology and Education \\ Tianjin, China
}

\begin{abstract}
Enterprise graduate innovative practice base is a reform of postgraduate training mode, but also an important platform for industry university research cooperation, which plays an important role in improving the independent innovation ability and innovative talents training. Enterprises should make full use of the advantages of human resources and science and technology in Colleges and universities, promote the cooperation between schools and enterprises, and promote the establishment of scientific and technological projects. The graduate innovative practice base will be the base for attracting and selecting talents, and innovation management and assessment mode will enhance the ability of enterprise innovation. We should strengthen the regular communication system between the teachers on campus and off campus, promote the enterprises to participate in the compilation and teaching of the textbooks, further expand the innovative practice bases for the training and practice bases for young teachers, and further expand the scope of the cultivation of innovative talents.
\end{abstract}

Keywords-Enterprise; Innovation practice base of graduate student; Cultivation of talents

\section{INTRODUCTION}

In recent years, with the rapid development of China's economy and society, many enterprises are faced with the lack of highly educated practical talents. At present, the scale of graduate enrollment in Colleges and universities continues to expand, and how to cultivate innovative talents with high comprehensive quality has become the top priority of graduate education in universities. In order to cultivate the innovative ability and practical ability of graduate students, enterprises and universities should cooperate with each other to set up innovative practice bases for postgraduates, so as to promote the practice of scientific and technological innovation and achievement transformation, and improve the quality of graduate education. Practice has proved that this mode of combining production, study and research has produced good results, promoted the development of graduate education, and explored a new way of graduate education [1].

The establishment of enterprise graduate innovative practice base, graduate students can make enterprise engineering problems condensed into scientific research topics, help enterprises to overcome technical problems, and carry out new product development. On the other hand, enterprises provide graduate students with research facilities and practical guidance conditions to carry out the training and training of graduate students. Therefore, the establishment of innovative practice base for postgraduates is the need for universities to give full play to the advantages of talents and science and technology, and to contribute to economic construction.

In order to improve the quality of applied professional degree graduate students and realize the successful transformation of graduate education, there is an urgent need to establish a number of innovative practice bases for graduate students. To explore the construction mode of graduate innovative practice base, to identify the positioning and the function of innovation practice base is the key to build a good innovation practice base, and to improve the quality of postgraduate training [2]. In view of the shortage of innovative graduate education, combined with the specific research conditions of schools and enterprises, this paper analyzes the training mode of "school enterprise" joint Postgraduate Innovative Practice Base.

\section{BASIC CONDITIONS FOR THE CONSTRUCTION OF PRACTICE BASES}

(1) Colleges and universities should choose the enterprises which are consistent with their own specialties and characteristics. The enterprises should have advanced and representative in the field of industry, and the enterprises should pay more attention to scientific research and attach importance to the development of science and technology [3].

(2) Enterprises should have the power to participate in school enterprise cooperation to train graduate students, have a good sense of social responsibility, understand the requirements of graduate training, and actively cooperate with the school for the joint training of students.

(3) Enterprises have good hardware and software infrastructure, in line with the relevant requirements of graduate training, can provide guarantee for innovative practice of graduate students

(4) The enterprise has a certain R \& D team, the advanced technical personnel in the team can provide better technical guidance and engineering teachers' guarantee for graduate students' training [4] 


\section{The Problem That Practice Base Construction PATTERN NEEDS TO SOLVE}

Institute of electrical engineering in Tianjin university of technology and education has many years of graduate student training experience, In the process of base construction mainly seek to solve the following several aspects:

(1) How to work well with the enterprise, arouse the enthusiasm of enterprises and enthusiasm on the part in university-enterprise cooperation, between the two sides how to formed in the security under the premise of mutual benefit and win-win results "schools and enterprises" joint training as a long-term mechanism.

(2) How to set up an experienced and professional enterprise tutor team, the team can meet the needs of enterprise technology research and development, provide good technical guidance for graduate students in the base period and service, strengthening graduate students ability to solve practical problems.

(3) How to effectively balance the graduate student academic and practical problems during enterprise base. Let graduate students combine theory with practice closely, make theory further improved.

(4) How to design a topic or research direction, conform to the requirements of every student's own interest and innovation, guarantee the graduate student can made some breakthrough in the research direction and progress, strengthen a high level of academic papers published. The construction of innovative practice base for innovative talents reserve follow-up force in our country.

\section{PRACTICE BASE CONSTRUCTION IMPLEMENTATION RESEARCH}

\section{A. Promote cooperation of school and enterprise and enhance the project of science and technology}

Enterprise graduate innovative practice base is guided by the government, the application for the establishment of enterprises, capital construction and the introduction of graduate students to carry out technical research and development base. The enterprise graduate innovative practice base is not only an innovative practice base for graduate students, but also an important platform for the cooperation of industry, University and research institute. Through cooperation, to improve the scientific and technological content of the product, to produce substantial results, can reflect the original intention of graduate innovative practice base construction, and promote the sustainable development of practice base. Therefore, school enterprise cooperation cannot stay on the surface, schools and enterprises can apply for the establishment of Tianjin Postgraduate Innovative Practice Base, Tianjin key laboratory and Tianjin Engineering Technology Center in further cooperation. At the same time, declare the joint declaration of Tianjin science and technology support projects and related science and technology projects of science and Technology Department

In order to strengthen the construction of graduate innovative practice base, the relevant schools have also established graduate innovation fund and other projects. The government of Tianjin has also provided special funds to support the construction of innovative practice bases for postgraduate education.

\section{B. Enterprises should take the postgraduate innovative practice Base as an opportunity to enhance the basic $R \&$ D capability}

Enterprises hope to develop new technology and new products through cooperation with colleges and universities to improve economic benefits. Only through basic research, we can find the scientific factors to improve the quality of products fundamentally, so as to improve the quality of products in essence. Basic research is the cornerstone of independent innovation, and the rapid development of biological and information technology industry is rooted in the development of basic research. Basic research will help enterprises to absorb external knowledge and promote innovation. Enterprises should change the old view of "taking, imitating and copying", and take the opportunity of establishing the innovative practice base for postgraduates, so as to give full play to the role of intellectual resources in Colleges and Universities.

\section{The graduate innovative practice base is the base of think tanks and talent selection}

Behind the graduate innovative practice base is the intellectual resources of the school, graduate and graduate tutor, give full play to their initiative, can make the base to become the enterprise think tank reserves.

Enterprises should take the Postgraduate Innovative Practice Base as the incubator for talent training and introduction, and make full use of the base resources to make it the base of think tanks and talent reserves. The graduate students have a long time to study in the station, and enterprises can conduct a long-term investigation on the comprehensive qualities of the graduate students' work ability, morality and skills. In addition, after graduation, stay in the enterprise work, can quickly competent work, for the development of enterprises to make greater contributions.

\section{Continuous innovation management}

At present, the Graduate Innovative Practice Base of enterprises is the co management system between enterprises and schools, and the graduate students are both graduate students and employees. Therefore, we cannot use the management mode of the school completely, and must combine the management mode of the enterprise and the school.

Tianjin university of technology and education set up a corporate innovation base for graduate students of the management committee, the daily management of the enterprises by the station enterprises responsible for the development of the enterprise innovation base for graduate students of management, enterprise and school cooperation design plan, raise research funds, security base instructors and graduate students the necessary research and living conditions school; set up a steering group, the main check into base 
project implementation, coordinate and handle the relationship between the contradictions at the same time. The management committee is responsible for the construction of the base and the management and assessment of the graduate students in the base, including the examination and approval of the base, the examination of the base, the ideological and political education, and the safety management. Such a management model defines the responsibilities and obligations of both sides, so that the work can be carried out smoothly[1].

\section{E. The establishment of the evaluation model}

Innovative management model also needs to be combined with assessment. The assessment should not only be combined with the project research plan as an indicator, but also need to combine with the training objectives of graduate students. We should not only consider the completion of the enterprise project research plan as the assessment target, but also need to investigate whether the academic level and innovation ability of graduate students achieve the training goal. Therefore, the academic committee of the college needs to strengthen the academic assessment of the graduate students entering the base, and implement incentive rewards and punishments system, such as setting up excellent graduate student model and other honorary titles to stimulate students' enthusiasm for learning and working in the base. Strengthening the management of dissertations. The implementation of enterprise project tasks and graduate training objectives combined assessment model, can achieve the goal of innovative talents training [5].

\section{F. Strengthen the regular communication system between on campus and off campus tutors}

At present, the graduate innovative practice base is generally implemented double tutorial system, in addition to equipped with school mentors, into the base of the study, the allocation of a senior enterprise management personnel or technical personnel as mentors. Enterprises lack of guidance of graduate tutor experience, so the school should strengthen the selection and assessment of school teacher, the elimination system, let the school teacher learning and mastering the training syllabus and plan of graduate students, the importance of strengthening the opening process, mid-term examination, and regular seminars [6]. School tutors can guide students to refine scientific problems from engineering projects, and cultivate students' innovative spirit. Students should regularly report and negotiate the progress of scientific research projects to the school tutors, and prevent the loss of the role of school mentors. At the same time, the regular communication system should be established between the tutors and the off campus supervisors [7].

\section{G. Strengthening the construction of relevant teaching materials and improving the teaching environment}

Graduate students entering the base are not equal to master of engineering, and can not weaken theoretical study. At present, graduate students usually complete the required theoretical study at school and then enter the innovation base. Enterprises usually do not undertake the relevant teaching work, nor interfere with the school teaching plan arrangement, which is a misunderstanding. At present, one of the main problems faced by the school teaching is outdated textbooks and disjointed with the market. Enterprises have a large number of professional knowledge, and the most understanding of the industry's latest technology and knowledge needs, therefore, enterprises have the responsibility to impart the latest knowledge system to base graduate students [8]. Schools should strengthen cooperation with enterprises, let enterprise personnel participate in the compilation of teaching materials, constantly revise the traditional teaching materials, inherit and innovate, help to update the teaching content, let the students can accept the latest knowledge. Strengthen the construction of teaching materials and teaching, through several years of cooperation, the completion of school, provincial and national quality courses, which is of great significance to the reform of postgraduate training mode and the cultivation of innovative talents.

\section{H. How to serve young teachers}

It is an important task to strengthen the practice teaching and practical ability training of young teachers. Young teachers, who have just graduated, especially young teachers who work in cross specialty, are not deep enough to understand the specialty, and need to strengthen the training of practical ability. Therefore, the graduate innovative practice base can also be an important platform for young teachers' training, and the base can provide a good external environment for young teachers to carry out scientific research and technological development. The school can be organized and planned to send the young teachers to graduate innovation practice base for job training, work, training and learning. Young teachers exercise in practice, can extract theoretical problems from the project, and better integrate theory with practice [9]. At the same time, it can help enterprises to find and solve problems, so as to promote the growth of young teachers.

\section{SugGestions ON THE CONSTRUCTION OF GRADUATE PRACTICE BASE}

In order to further standardize the construction of graduate practice base and give full play to the expected function, several suggestions are put forward.

\section{A. Strengthen publicity and raise awareness}

Graduate practice base as a new form of cooperation platform, we must strengthen the propaganda in school teacher, every teacher makes clear the platform of training, scientific research and social service function in talent, encourage teachers to carry out research on major technical requirements of enterprises, strengthen research cooperation to promote the sense of ownership, opportunity awareness and sense of responsibility and a sense of mission, to encourage more students to join the research team innovation practice base. 


\section{B. Establish a multi-channel funding mechanism}

The government set up special funds for graduate practice base to provide financial support for outstanding projects, further reduce the risk of enterprise technology investment, and improve the enthusiasm of enterprises and schools for the construction of this platform. The school set up special funds for Graduate Innovative Education, giving priority to the practice base construction and cultivation projects, and the continuous growth of school funding is the guarantee of improving the quality of postgraduate training. Enterprises in the project funding should be clear that a certain proportion of graduate students should be used for base projects.

\section{Research on building a mutually beneficial and win-win cooperation mechanism}

Whether the practice base can run for a long time and whether there is an ideal result depends on the participants, that is, school supervisors, enterprise mentors, graduate students and enterprises. In the whole process of project implementation, there will be more or less problems. The core of these issues is mutual benefit and win-win cooperation mechanism. The quantitative mechanism of mutual benefit and win-win sharing rights as a symbol of cooperation is the key of long-term operation of the practice base, in the base project preliminary quantitative results of attribution, including research enterprise proportion, involved in the project, both supervisors and other personnel rights, and finally by the base management mechanism according to the appraisal confirmation or adjustment of rights sharing scheme.

\section{Improve the system construction and strengthen the implementation}

The daily operation of enterprise graduate practice base needs the system guarantee, and the function depends on the mechanism. The school and enterprise should pay attention to the construction of mechanism in practice, perfect the relevant system and implement the system. A series of management mechanisms, such as the process of project management, the assessment mechanism of contract management, the multichannel funding mechanism, the dual tutorial system and the supervision system, should be improved continuously in practice. At the same time, we should strengthen the training of enterprise instructors

\section{CONCLUSION}

The establishment of innovative practice base for graduate students is not only the need of postgraduate training mode reform, but also an effective platform to promote the cooperation of industry. University and Research Institute can greatly promote the development of graduate education, accelerate the integration of university into society, promote the progress of science and technology and the transformation of achievements, improve the enthusiasm of enterprises to participate in postgraduate training, and enhance the sense of responsibility and mission. which is of great significance for the construction of an innovative country. The government, enterprises and universities should work closely together to strengthen the construction of innovative practice bases for postgraduates, so as to enhance the ability of independent R \& $\mathrm{D}$ and international competitiveness.

\section{REFERENCES}

[1] Xiang Zhang, Research on the quality guarantee mechanism of enterprise graduate workstation training, $[\mathrm{J}]$. Education for chinese After-school. 2012(16): 54-55.

[2] Guijuan Lin, Zhaomei Yu, Tian Wang, Research on practice base construction mode of professional degree graduate students, $[\mathrm{J}]$. China Agricultural Education. 2012, (01): 50-52+96.

[3] Xisheng $\mathrm{Hu}$, Rongzu Qu, Zhengxiong Zhang, Discussion on the construction mode of Graduate Innovative Practice Base, [J]. Journal of Changchun University of Science and Technology. 2012(05) 106-107.

[4] Haixia Shi, Research and Practice on the construction of postgraduate training base, [J]. University Education.2013(19): 9-10.

[5] Qun Wu, Yan Xu, Reform and innovation of graduate workstation training mode, [J]. China Education of Light Industry. 2011(06):6-7.

[6] Jinrong Shen, Kai Lei. The current Chinese enterprise graduate practice base existing problem and countermeasure research, $[\mathrm{J}]$. Journal of Nanjing University of Science and Technology(Social Science). 2011,24(5):92-96

[7] Lishan Xiao,Workstation and graduate student innovation ability training, [J].Petroleum Education. 2010(02) 74-76.

[8] Yu Huang, Master's degree graduate practice teaching research in colleges and universities, [D]. South-Central University for Nationalities. 2012

[9] Fengcai Ma,Yongxia Guo, The function of the graduate student practice base and its implementation.[D]. Heilongjiang Bayi Agricultural University.2013. 